\title{
Suárezove vječne istine i Descartesova Treća meditacija
}

Predrag Milidrag*

\begin{abstract}
Sažetak
U prvom dijelu rada izlaže se Suárezovo razumijevanje vječnih istina. Tri su momenta relevantna za tumačenje Descartesa: hipotetička nužnost vječnih istina, uloga djelotvornog uzrokovanja $i$ vječne istine o bićima razuma. $U$ drugom dijelu teksta brani se teza da 16. odlomak Treće meditacije (AT VII 42) sadržava dvije suarezijanske vječne istine $i$ da obje tvrde da Bog postoji. Između ostalog, to vodi zaključku da taj odlomak Treće meditacije zapravo sadržava Descartesovu nestvorenu vječnu istinu o egzistenciji Boga (AT I 150).

Ključne riječi: vječne istine, nestvorene vječne istine, Meditacije, Suárez, Descartes, potentia objectiva, egzistencija Boga
\end{abstract}

\section{Uvod}

Poimanje kasne skolastike predugo je ovisilo o povjesničarima filozofije: oni koji su se bavili srednjim vijekom smatrali su da je ona dio renesansne ili rane moderne filozofije, a oni koji su obrađivali ranu modernu filozofiju gledali su na nju kao na dio skolastičke. ${ }^{1} \mathrm{Na}$ Suárezovu primjeru možda se ponajbolje vidi unutrašnji razlog zašto je to razdoblje tako dugo bilo na marginama interesa. Jednostavno, s protomodernim uvidima ${ }^{2}$ doctora eximiusa skolastika nije znala što bi radila, jer to više nisu bili njezini uvidi, a novi vijek nije ih prepoznao kao neskolastičke, jer su iznijeti u kontekstu skolastičkog načina mišljenja i skolastičkih problema, iako su bili izlagani na skolastici ne baš blizak način, u obliku čisto filozofske rasprave o metafizici, ne u obliku komentara, opuscula ili suma.

* Dr. sc. Predrag Milidrag, viši znanstveni suradnik, Institut za filozofiju i društvenu teoriju, Sveučilište u Beogradu. Adresa: Kraljice Natalije 45, 11000 Beograd, Srbija. E-pošta: predrag.milidrag@gmail.com

1 Osnovu teksta čini izlaganje na konferenciji „Filozofija i pravo. Znanstveni skup prigodom 400. obljetnice smrti Francisca Suáreza SI (1548. - 1617.)“, održanoj 14. studenoga 2017. na Fakultetu filozofije i religijskih znanosti Sveučilišta u Zagrebu.

2 Karakterizacija Ferratera Joséa More (Mora, 1953, 529). Za prikaz i analizu različitih teza o Suárezu kao osnivaču modernog razdoblja usp. Miner, 2001. Španjolski teolog zasigurno nije bio utemeljitelj moderne filozofije, što je stav koji de facto zastupa José Pereira (2007). 
Samo nedostatak upoznatosti sa Suárezom i kasnom skolastikom stvorio je uvjerenje kod filozofa da su moderna kretanja bila apsolutno originalne tvorevine. Izdvojimo neke Suárezove uvide kojima on pravi iskorak ka ranoj modernoj filozofiji. Suočen s osnovnim problemom metafizike pripisuje li se biće (ens) jednoznačno ili višeznačno svemu što jest, bez ijednog skolastičkog prethodnika on se opredijelio da stanje duha (conceptus formalis entis) učini kriterijem za jedinstveni smisao, zato što nam je ono poznatije jer je proizvedeno u nama i za nas (DM 2.1.1; vol. 25, 65). ${ }^{3}$ Nadalje, on koristi kao kriterij za izvjesnost distincte et clare rem conceptam (DM 8.3.18; vol. 25, 288) te smatra da je za izvjesnost nužno eliminirati mogućnost angelus malusa pozivajući se, doduše, na objavljenu istinu kao garanciju toga da Bog nije prijevaran (DM 9.2.7; vol. 25, 323). Za njega ne postoji uzročna veza između duhovne i materijalne sfere u spoznaji, nego samo egzemplarna uzročnost: osjetna predodžba samo daje povod za proizvođenje inteligibilnog lika. Riječ je, dakle, o okazionalnom uzrokovanju (ne o okazionaliz$\mathrm{mu}$ ), što je bio put koji je vodio do Descartesova dualizma.

Zahvaljujući pionirskomu radu povjesničara filozofije posljednjih desetljeća 20. stoljeća, danas znamo da se Descartesova teorija ideja čvrsto temelji na kasnoskolastičkom učenju o ljudskom činu poimanja i učenju o božanskim idejama. Norman Wells pokazao je da je svoje učenje o stvorenosti vječnih istina francuski filozof izgradio na putu Suárezova razumijevanja. ${ }^{4}$ Descartesova je metafizika proizišla iz kasnoskolastičke filozofije, u njoj ostaje ukorijenjena i njome hranjena: od upotrebe tipično kasnoskolastičkih pojmova kao što su conceptus formalis i esse objectivum (AT VII 78; AT VII 102-103, 151, 232-235) ili suarezijanskog izraza non nihil (AT VII 41, 64-65) ili suarezijanske karakterizacije ideje kao slike stvari (AT VII 37), ${ }^{5}$ preko štostvenog pojma bića, ${ }^{6}$ do suarezijanske razumske razlike između biti i egzistencije u stvorenjima (usp. AT V 164; AT IV 349; AT VII 166). Cartesiusova tri smisla ideje, u formalnom, objektivnom i materijalnom smislu (usp. AT VII 166), neposredno se i neporecivo temelje na kasnoskolastičkim pojmovima conceptus formalis i conceptus objectivus.

Također, u Četvrtim odgovorima na Primjedbe na Meditacije on se eksplicitno poziva na Metafizičke rasprave i Suárezovo razumijevanje materijalne lažnosti ideja kao izvor za vlastito razumijevanje (AT VII 235). Nije mi poznato da se igdje drugdje ikad pozvao na točno određeno mjesto kod nekog od svojih prethodnika.

3 Usp. DM 2.1.9; vol. 25, 68. Za objektivni koncept bića vidi: DM 2.2.8 i 14; vol. 25, 72 i 74. Walter Hoeres pokazao je da naizgled Suárez u Raspravama negira jednoznačnost pojma bića, ali ta je negacija čisto formalne prirode te zapravo univočnost naširoko koristi (Hoeres, 1965). Isto tvrdi i pokazuje Jorge Secada $(2006,73)$.

4 Više o tome u: Wells, 1984; Wells, 1990; Wells, 1993.

5 »Ideja Boga [...] je slika istinske i nepromjenljive naravi (imaginem verae et immutabilis naturae) « (AT VII 68).

6 Na to jasno ukazuje stvar koja je »preko ideje objektivno u razumu « (AT VII 41), već spomenut suarezijanski pojam non nihil ili govor o Bogu kao mogućem biću (AT VII 119, 152, 163). 
Utjecaj kasne skolastike na obrazovanje Descartesove epistemologizirane metafizike već je pristojno obrađena tema u sekundarnoj literaturi, ${ }^{7}$ te bih stoga u nastavku pokušao pokazati kako nam Suárezove vječne istine mogu pomoći da na drugačiji način razumijemo jedno mjesto iz Treće meditacije. U skladu s tim, ovo izlaganje ima dva dijela. U prvom je riječi o tome kako je Suárez razumijevao vječne istine, a drugi je posvećen Trećoj meditaciji.

\section{Suárez o vječnim istinama}

Svoje razumijevanje vječnih istina omnium metaphysicorum Papa, kako su Suáreza nazivali na onovremenim protestantskim fakultetima (Noreña, 1984, 21), izlaže u 31 metafizičkoj raspravi, u kontekstu razmatranja odnosa biti i egzistencije (existentia) u konačnim bićima. Taj problem on obrađuje u tijesnoj vezi s problemima božanske egzemplarne uzročnosti i statusa stvorenja u božanskom duhu prije čina pridavanja realne egzistencije njihovim bitima, jer vječne istine o bitima stvorenih stvari tvrdnje su kojima je izražena nužnost odnosa koji postoje između predikata u nekoj biti ili nužnost pripadanja nekog predikata dotičnoj biti. Praktično, znanje o jednoj biti iscrpljuje se u znanju svih vječnih istina o njoj: »Istina o biti uistinu nije ništa drugo do sama bit«, kaže Suárez (DM 31.12.43; vol. 26, 296), a isto kaže i Descartes: »I te biti [stvāri] nisu ništa drugo nego vječne istine « (AT I 150). Osim toga, tu je sasvim očit izvor Leibnizova kompletnog pojma.

Za mislioca iz Granade, vječne istine utemeljene su na nekom načinu bivstvovanja biti stvari. Tri su načina aktualnosti biti: izvan svojih uzroka, u razumu i u svojem uzroku. U prvom slučaju, bit posjeduje unutrašnju aktualnost u sebi samoj (DM 31.3.5; vol. 26, 234), a druga su dva načina ekvivalentna ako je uzrok razumske prirode, kakav Bog jest, i bit tada posjeduje aktualnost u svojem uzroku.

Budući da, da iskoristimo klasičan skolastički primjer, to što je ruža znamo čak i onda kada na svijetu nema ni jedne ruže,${ }^{8}$ istine o bitima stvari očito su nezavisne od realnog egzistiranja stvari kojih su one biti. Preostaje ispitati njihovo bivstvovanje u božanskom duhu. „Bivstvovati u Bogu kao u svojem uzroku” znači da biti stvorenja imaju odnos i prema njegovu razumu i prema njegovoj volji. Grubo govoreći, odnos prema Božjem razumu imaju zato što je Bog misleće biće, a odnos prema njegovoj volji imaju zato što je Bog njihov uzrok. Otud, „bivstvovati u svojem uzroku" za biti stvorenih stvari znači prethodno bivstvovati kao objekt božanske svemoći. Zavisnost biti stvorenih stvari od božanske svemoći znači da su one od Boga zavisne kao od svojeg djelotvornog uzroka (causa efficiens), odnosno moguće je reći da su, i za Suáreza, biti stvari stvorene: »Jer Bog

7 Osim nezaobilaznih tekstova Normana Wellsa, pažnju zavrjeđuju i sljedeći radovi: Clemenson, 2007; Schmitter, 1996; Costa, 1983; Cronin, 1966; Nadler, 1989.

8 Isti primjer koristi i Descartes (AT V 160). 
jedini stvara bit bez pretpostavljanja [ijedne druge] biti i posljedično on jedini stvara izravno i bitno stvorenu bit onakvu kakva ona jest. «9

Budući da je objekt božanskog razuma, bit dobiva vanjske oznake esse cognitum i esse objectivum, bivstvovati-kao-od-Boga-znan i bivstvovati-kao-objekt-božanske-svijesti i njih bit dijeli s bićima razuma (DM 31.2.7 i 54.1.10; vol. 26, 231 i 1018). ${ }^{10}$ Osim toga, bit stvorenja zadobiva i vanjsku oznaku esse potentiale objectivum, tj. bivstvovati-kao-objekt-božanske-svemoći (DM 31.3.4; vol. 26, 234). Za samu bit to znači da dobiva potenciju za realno egzistiranje ili potentia objectiva, odnosno kao-objekt-božanske-svemoći-imati-potenciju-za-realno-egzistiranje. Bića razuma ne mogu imati esse potentiale objectivum ni potentia objectiva, ona nisu objekti božanske svemoći, nego isključivo božanskog razuma (DM 31.2.2; vol. 26, 229), jer se protive realnomu egzistiranju. Cjelokupna se njihova stvarnost iscrpljuje u bivstvovanju-kao-biti-objekt-božanskog-razuma (DM 54.1.6; vol. 26, 1016). ${ }^{11}$

Budući da je riječ o potenciji za egzistiranje izvan svojeg uzroka, to podrazumijeva prisustvo djelotvornog uzrokovanja u biti stvorenja (DM 31.6.13; vol. 26, 246). Budući da je upravo potentia objectiva izraz stvarnosti biti (stvari), slijedi da se one ne mogu adekvatno razumjeti odvojeno od svojeg djelotvornog uzroka (ako egzistiraju realno) ili barem od potencijalnog djelotvornog uzroka (ako imaju samo moguću egzistenciju) (DM 31.2.5; vol. 26, 230).

Razmotrimo jednu vječnu istinu, primjerice „čovjek je razumna životinja”, kojom je izražena nužnost pripadanja predikata „,imati razum” i „biti životinja” jednoj biti, ljudskoj. Suárez tvrdi da od razumijevanja kopule ,je” u vječnim istinama ovisi i razumijevanje njihove prirode. Kopula ,je” u vječnim istinama o stvorenim stvarima svakako označava biće, ali što točno označava?

Ponekad se uzima kao particip glagola jesam i kao takvo označava čin bivstvovanja kao izvršen te je isto što i aktualno egzistiranje; no ponekad je uzeto kao imenica, označavajući formalno bit svoje stvari, koja ima ili može imati bivstvovanje ne kao izvršeno u činu, nego u potenciji ili sposobnosti, baš kao što življenje kao particip označava aktualno očitovanje života, a kao imenica označava samo ono što ima prirodu koja može biti načelo životnih operacija. ${ }^{12}$

Dakle, uzeto kao particip biće označava sam čin realnog egzistiranja, jednu bit koja je aktualna u svijetu kao bit neke realno egzistirajuće stvari, a kao ime-

9 »Nam solus Deus facit essentiam, nulla praesupposita essentia, et consequenter solus ipse facit per se primo essentiam creatam, ut talis est « (DM 31.9.25; vol. 26, 266). Za kasnoskolastičku raspravu u vezi s uzrokovanjem biti i vječnih istina vidi: Coombs, 2003.

10 Oznaka je vanjska jer je pridošla od nečeg samoj biti vanjskoga, od spoznajućeg duha (usp. Doyle, 1984).

11 Za detalje Suárezova razumijevanja bića razuma vidi: Doyle, 1987; Doyle, 1988.

12 »Ens ergo, ut dictum est, interdum sumitur ut participium verbi sum, et ut sic significat actum essendi ut exercitum, estque idem quod existens actu; interdum vero sumitur ut nomen significans de formali essentiam eius rei quae habet vel potest habere esse, et potest dici significare ipsum esse, non ut exercitum actu, sed in potentia vel aptitudine, sicut vivens, ut est participium, significat actualem usum vitae, ut vero est nomen significat solum id quod habet naturam quae potest esse vitalis operationis principium «(DM 2.4.3; vol. 25, 88). Usp. također: DM 2.4.7 i 9; vol. 25, 89 i 90. Za stvarnu bit kao rezultat poimanja bića kao imenice usp. DM 2.2.5, vol. 25, 89-90. 
nica označava biti kao takve, nezavisno od njihove aktualnosti u svijetu, pri čemu je realna egzistencija apstrahirana od same biti: »Bice [...] nije pripisano samo egzistirajućim stvarima, nego i stvarnim prirodama promatranim u sebi samima, egzistirale one ili ne. To je način na koji metafizika razmatra biće i na taj je način biće razdijeljeno u deset kategorija «. ${ }^{13}$ Razlika između bića kao participa i kao imenice samo je stupanj apstrakcije: biće kao particip specijalan je slučaj bića kao imenice i njime se označavaju samo aktualne biti, a bićem kao imenicom označavaju se i aktualne i one koje bivstvuju samo u nekom razumu. ${ }^{14}$

Kopulom „je” u razmatranoj vječnoj istini „čovjek je razumna životinja“ svakako nije označeno biće kao particip jer, s jedne strane, vječne istine postoje i o neaktualnim bitima, a bit čovjeka nije nužno aktualna, s druge. Vezanost vječnih istina za nenužnu aktualnost značila bi da su vječne istine o čovjeku istinite samo ako ima realno egzistirajućih ljudi (DM 31.12.38; vol. 26, 294).

Postojanje vječnih istina i o neaktualnim bitima stvorenih stvari, kao i njihova nevezanost za aktualno bivstvovanje jasno upućuje na to da je kopulom ,je” u vječnim istinama izraženo biće kao imenica, što znači da se razumijevanje vječnih istina kreće $u$ kontekstu stvarnih biti, to jest u kontekstu bivstvovanja biti stvorenih stvari u Božjem duhu. Drugačije rečeno, pošto je kontingentna realna egzistencija uzrokovana, istinitost vječnih istina o stvorenjima ne ovisi od Božje aktualne djelotvorne uzročnosti.

Nužnost i istinitost vječnih istina o bitima stvorenih stvari utemeljene su u bitima stvorenja kao bivstvujućim u svojem uzroku. Kazali smo da „bivstvovati u svojem uzroku" za biti stvorenja znači biti kao objekt božanske svemoći (esse potentiale objectivum), jer je ta svemoć njihov uzrok. ${ }^{15}$ Samim tim, i temelj vječnih istina mora biti esse potentiale objectivum, ${ }^{16}$ a kopula ,je" mora označavati

13 »Rursus constat ex communi usu ens [...] non solum tribui rebus existentibus, sed etiam naturis realibus secundum se consideratis, sive existant, sive non; quomodo metaphysica considerat ens, et hoc modo ens in decem praedicamenta dividitur « (DM 2.4.3; vol. 25, 88).

14 O apstrakciji realne egzistencije od biti vidi: DM 31.6.15 i 21; vol. 26, 246 i 249. Treba imati u vidu da su Tominu precizirajuću apstrakciju Suárez i svi kasniji skolastici nazivali negativnom. O precizirajućoj i neprecizirajućoj apstrakciji vidi poglavlja 2 i 3 u tekstu O biću i biti (Toma Akvinski, 1996, 276-300). O precizirajućoj apstrakciji kod Tome vidi: Owens, 1963, 63-64; 132-133. O precizirajućoj apstrakciji kod Suáreza vidi: Secada, 2000, 223-224. O razlikovanju bića kao imenice i kao participa u 16. stoljeću vidi: Doyle, 1982, 108. O razlikovanju bića kao imenice i kao participa kod Suáreza vidi: Noreña, 1984. U skolastici je razlikovanje bilo opće mjesto. O Kajetanu (Thomas de Vio, Caietanus), Silvestru iz Ferare (Francesco Silvestri) i Pedru Fonseki (Petrus Fonseca) vidi: Pereira, 2007, 8 i 109. O Fonseki i komentatorima sa Sveučilišta u Coimbri (takozvani Conimbricenses) vidi: Clemenson, 2007, 14.

15 Nipošto se ne smije previdjeti ranije rečeno da je bivstvovanje kao objekt svemoći ekvivalentno a ne identično s bivstvovanjem u razumu. Biti bivstvuju i kao objekti Božjeg razuma (esse objectivum/cognitum) jer Bog kao njihov uzrok ima razumsku prirodu, ali njihova istinitost i nužnost počivaju na odnosu ne prema njegovom razumu, nego prema njegovoj svemoći. U tom se Suárez, barem prema ovdje izloženoj i prema Wellsovoj interpretaciji, razlikuje od Tome. Za drugačije interpretacije Suáreza vidi primjerice: Karofsky, 2001a; Karofsky, 2001b. Za drugačiju interpretaciju Tome tekst o vječnim istinama kod Akvinca u: Maurer, 1990.

$16 »$ Haec autem connexio non fundatur in actuali esse, sed in potentiali« (DM 31.2.8; vol. 26, 231), u prijevodu: »Ta veza [između čovjek i razumska životinja] nije utemeljena na aktualnom bivstvovanju, nego na bivstvovanju u potenciji.« 
unutrašnju vezu između biti i predikata kao objekata božanske svemoći (prisustvo uzročnosti je očito). Kao objekti božanske svemoći, biti stvari nemaju realnu egzistenciju, ali imaju potenciju za takvu egzistenciju (potentia objectiva). Otud će i nužnost koju izražava kopula ,je“ biti utemeljena na potenciji biti za realno bivstvovanje, a vječna će istina nešto govoriti o realnom bivstvovanju biti stvari.

Budući da je riječ tek o potenciji za realno egzistiranje, kopula može izražavati samo jedno hipotetički nužno esse, pa će, otud, i nužnost vječnih istina biti hipotetička: vječna će istina govoriti o aktualno bivstvujućoj biti stvorene stvari ako stvar čija je ona bit realno egzistira. Konkretno, vječna istina „čovjek je razumna životinja" u Suárezovoj interpretaciji znači: ako realno egzistira, čovjek će posjedovati razum i bit će životinja: »Propozicije u tom smislu reducirane su na hipotetički ili uvjetni smisao. Jer, kada kažemo da je čovjek životinja, apstrahirajući od vremena, ne kažemo ništa drugo nego da je to priroda čovjeka, naime da je za njega nemoguće da počne postojati a da ne bude životinja « (DM 31.12.45; vol. 26, 297). ${ }^{17}$ Ono što Bog zna u vječnim istinama jest hipotetički istinito esse; on zna egzistenciju kakvu bi stvar imala ako bi bila stvorena, tj. realno egzistirala (usp. DM 31.12.45; vol. 26, 297). Hoće li određena bit jedne stvorive stvari i bivstvovati aktualno (kao jedna u svijetu realno egzistirajuća stvar) zavisi od Boga i njegove aktualne djelotvorne uzročnosti.

Kada je riječ o vječnim istinama, rečeno znači da su one nužne i istinite zato što se njima zapravo tvrdi jedino to da ne bi slijedilo ništa proturječno ako bi njima izražene unutrašnje veze između biti i predikata bile aktualne. Za Suáreza vječne istine nisu to što jesu zato što bi bile nezavisne od Boga, kao kod Capreola, niti zato što su objekti njegova razuma, kao kod Tome, niti zbog božanskog znanja budućih događaja. Budući da su istinite tvrdnje, one se svakako nalaze i u Božjem razumu, ali nisu od njega, nego su od božanske svemoći i istinite su zahvaljujući toj svemoći.

Osim o bitima stvorenja, postoje i vječne istine o bićima razuma. To su hipotetičke tvrdnje kako o mogućim tako i o nemogućim stvarima: „himera je izmišljeno čudovište“ ili „,ako je kamen životinja, on je sposoban osjećati“ ili pak „ako je čovjek životinja, on je sposoban osjećati“, to su sve Suárezovi primjeri. Kopula „je“ u tim vječnim istinama ne može označavati biće ni kao particip ni kao imenicu. Rekli smo da, za razliku od biti stvorenih stvari, bića razuma nisu objekti božanske svemoći, nego su isključivo objekti božanskog razuma (DM 31.12.45; vol. 26, 297), dakle posjeduju isključivo esse objectivum/cognitum. Zato će kopula „je” u njima označavati samo bivstvovanje istine propozicije (esse veritas propositionis) (DM 31.1.2; vol. 26, 255) ${ }^{18}$ i one su vječne i istinite zato što ih Bog vječno zna, kaže Suárez (DM 31.12.40; vol. 26, 294-295). ${ }^{19}$

Da dodatno pojasnimo, „ako čovjek postoji, on je životinja“ jest istina o jednoj stvarnoj biti (ne o biću razuma), jer u sebi sadržava egzistencijalnu pretpostavku i

17 Za ovisnost istinitosti od djelotvornog uzroka usp.: DM 31.2.8 i 31.12.45; vol. 26, 231 i 297.

18 Usp. također: DM 31.2.8 i 11; vol. 26, 231 i 232.

19 Za vrlo informativno izlaganje o vječnim istinama o bićima razuma kod Suáreza, vidi treće poglavlje u: Cantens, 2000. 
ukazuje na to da se takva bit ne protivi realnoj egzistenciji. S druge strane, istina „ako je kamen životinja, on je sposoban osjećati“ jest istina koja se temelji na bivstvovanju istine propozicije, ne sadržava egzistencijalnu pretpostavku (jer nije realna bit) i tek govori o odnosu predikata unutar biti, protivila se ona realnoj egzistenciji, kao kod bića razuma, ili ne. Suárez tvrdi da »ako per impossibile nema takvog uzroka, takve bi izreke još uvijek bile istinite, baš kao što je ovo istinito: Himera je himera i slično ${ }^{20}$

\section{Treća meditacija: Alternative kao vječne istine}

Za tumačenje mjesta iz Descartesove Treće meditacije bitna su tri momenta u Suárezovu razumijevanju vječnih istina: prvo, za Suáreza vječne istine o bitima stvorenih stvari izražavaju hipotetičku nužnost odnosa između predikata biti u odnosu na realnu egzistenciju i njima se tvrdi da ne bi slijedilo ništa proturječno ako bi njima izražene unutrašnje veze između biti i predikata bile aktualne. Drugo, vječne istine pokazuju da se same te biti ne mogu adekvatno razumjeti odvojeno od svojeg djelotvornog uzroka. Treće, postoje i vječne istine o bićima razuma koje su hipotetičke tvrdnje koje ne govore ništa o realnoj egzistenciji.

Sa Suárezom na umu, čitamo 16. odlomak Treće meditacije:

A što te stvari duže i pomnije istražujem, sve jasnije i odjelitije spoznajem da su istinite. Ali što da iz toga zaključim?

Ako je objektivna stvarnost neke od mojih ideja takva da sam siguran kako ona nije u meni ni formalno, ni eminentno, niti da ja sam mogu biti uzrokom te ideje, onda neminovno slijedi da nisam u svijetu ja sam, nego da egzistira i neka druga stvar, koja je uzrok dotične ideje.

Ako pak u meni nema nikakve takve ideje, onda ne znam nikakva argumenta koji bi me uvjerio u egzistenciju bilo koje stvari različite od mene; sve sam pomno razmotrio, i nisam mogao dosad otkriti nikakva drugog. (AT VII 42)

Da pojednostavimo: Descartes kaže da ako je njegov duh uzrok sadržaja svih svojih ideja, onda slijedi da nije moguć dokaz da još nešto realno egzistira, ako pak duh nije uzrok svih svojih ideja, onda nužno slijedi da još nešto egzistira. Kada je riječ o samom meditativnom subjektu, pitanjem o uzroku stupnjeva objektivne stvarnosti ideja pitano je je li bit subjekta takva da može uzrokovati sadržaje svih svojih ideja. ${ }^{21}$

20 »Si per impossible nulla esset talis causa, nihilomnius ille enuntiatio vera esset, sicut haec est vera, Chymera est chymera, vel similis« (DM 31.12.45; vol. 26, 297).

21 Nema dovoljno prostora za puno objašnjenje pojma „stupnja objektivne stvarnosti ideja“ kod Descartesa. U najkraćem, riječ je o predikatu biti, o stupnju nezavisnosti njezina mogućeg realnog egzistiranja, dakle nije riječ o puko epistemološkom momentu: ne to zašto imam ideju drveta, nego to zašto ono reprezentirano njome jest jedna supstancija, a ne modus, i zašto ne može biti modus. O stupnju stvarnosti kao predikatu biti vidi primjerice: AT VII 434 i 165 . Za razliku između Descartesova razumijevanja i kasnoskolastičkog vidi Prve primjedbe na Meditacije i Descartesove odgovore. 
Sadržava li 16. odlomak Treće meditacije dvije suarezijanske vječne istine? Tvrdim da sadržava. Prvo, prisutna je hipotetička nužnost u objema tvrdnjama. Drugo, barem jedna od te dvije tvrdnje govori nešto o realno bivstvujućoj biti: meditativni subjekt ima jednu bit ako može biti uzrok stupnjeva objektivne stvarnosti svih svojih ideja, a sasvim drugačiju ako to ne može. Treće, kao konstitutivni moment javlja se djelotvorna uzročnost kada se govori o tome kakva je bit meditativnog subjekta i četvrto, na temelju Načela filozofije znamo da su te alternative jasne po naravnoj svjetlosti i da se naravnom svjetlošću spoznaju vječne istine (AT VIIIA 8, 12, 23 i 31).

Promatrano s obzirom na predloženo suarezijansko zaleđe, te vječne istine mogu se promatrati iz perspektive objavljena dva cilja Treće meditacije: prvi je ispitati postoji li još nešto izvan mene (AT VII 35), a drugi ispitati egzistira li Bog. Ti se ciljevi prepliću, ali nisu identični.

U odnosu na ispitivanje postoji li još nešto izvan duha, same formulacije u odlomku 16 govore da na tom mjestu Treće meditacije Descartes ne zna koja je od tih dviju vječnih istina govori o njegovoj biti. S obzirom na alternativu, na temelju uvida u ideju koju ima o sebi samom, ljudski duh ne može znati može li biti uzrok svih ideja, zato što su duhu njegove sposobnosti poznate tek na temelju djelatnosti tih sposobnosti (AT VII 246). Otud, odgovor na pitanje je li duh uzrok svih ideja, odnosno koja od dvije vječne istine govori o njegovoj biti, nužnim načinom jest iskustven i ispitivanje da bi to utvrdio Descartes provodi u odlomcima 17-22 Treće meditacije.

Posljedica je takvog tumačenja i teza da na tom mjestu Meditacija subjekt ne zna sa sigurnošću da je konačan, jer alternativa bi bila suvišna ako bi se tu posjedovalo znanje o konačnosti: zašto ispitivati mogu li biti uzrok svih svojih ideja ako već znam da sam konačan i da stoga ne mogu biti uzrok sadržaja ideje beskonačnog Boga koja je uvedena ranije? Nadalje, konačnost Descartes spominje tek u 26. odlomku, nakon izvođenja dokaza (AT VII 46-47) i sve do dokaza za dualizam duše i tijela u Šestoj meditaciji on uopće ne zna što je njegova bit.

Promotrimo sada vječne istine 16. odlomka s obzirom na cilj Treće meditacije, izražen u njezinu naslovu $O \mathrm{Bogu}$, da egzistira te potpuno ostavimo po strani „epistemološku“ dimenziju. Naime, ako ne mogu biti uzrok svih svojih ideja, onda u svijetu postoji još neka stvar koja posjeduje apsolutno nezavisnu realnu egzistenciju. Ako pak mogu biti uzrok svih svojih ideja, onda je nedokazivo postojanje ičega izvan mene, a ja sam mogu biti ta stvar s apsolutno nezavisnom realnom egzistencijom. Dakle, iz „dokazivo je da još nešto osim mene realno egzistira” slijedi da Bog egzistira, ali i iz „nedokazivo je da još nešto osim mene realno egzistira" također slijedi da Bog egzistira, tj. ja sam.

Ako je cilj dokazati da Bog postoji, ako se u tom svjetlu sagledavaju te vječne istine, onda je zaista nebitno tko je on. Filozofski promatrano, to da ja sam nisam Bog irelevantno je za dokaz za egzistenciju Boga. Descartes apsolutno dopušta mogućnost da je sam meditativni subjekt Bog jer u 18. članku prvog dijela Načela filozofije govori o nužnosti realne egzistencije najsavršenijeg uzroka svih ideja: »Po prirodnom je svjetlu naime sasvim očevidno« ne samo da vrijedi uzročno na- 
čelo »nego da i u nama ne može postojati ideja ili slika stvari kojoj ne bi postojao negdje, bilo u nama bilo izvan nas, neki pralik koji stvarno sadržava sva njezina savršenstva (AT VIIIA 12). ${ }^{22}$ Dakle, vječna je istina postojanje arhetipa bilo u nama bilo izvan nas. Osim toga, ni tu Descartes ne spominje znanje o konačnosti kao argument, jer ga riječi »bilo u nama« obesmišljavaju. U tom svjetlu, nastavak te meditacije, odlomci 17-22 ništa ne doprinose dokazivanju Boga, nego samo dokazivanju da sam meditativni subjekt nije Bog.

Vidimo tu bitnu razliku između dvije vječne istine u 16. odlomku kada je riječ o čovjeku i o Bogu: potrebno je empirijski ispitati koja od dvije vječne istine jest istina o jednoj stvarnoj biti, naime mojoj, ali vječna istina o egzistenciji Boga bjelodana je bez ikakve empirije, jer on svakako egzistira, ma tko da je on (»bilo u nama, bilo izvan nas«).

Upravo rečeno razotkriva jednu neobičnu osobinu te posljednje vječne istine, o Bogu: u 16. odlomku ja još uvijek ne znam koja je od dvije vječne istine istina o mojoj biti (na temelju načela neproturječnosti znam da jedna od njih zasigurno to jest), ${ }^{23}$ no na temelju njih zasigurno znam da Bog postoji.

Ako iz obje vječne istine slijedi da postoji Bog, to znači da nam 16. odlomkom Cartesius tvrdi da je bjelodana jedina vječna istina koja govori o realnoj egzistenciji nečega, naime o egzistenciji Boga. ${ }^{24}$ Za Descartesa, kao i za Suáreza, vječne istine ne govore ništa o realno egzistirajućim stvarima (AT IV 442), a istine koje govore o realnoj egzistenciji su kontingentne (AT V 167). Ipak, Descartes bi svakako dodao: ne govore, osim jedne jedine. »Egzistencija Boga prva je i najvječnija od svih istina koje mogu biti i jedina je iz koje sve ostale proizlaze « (AT I 150). Suarezijansko tumačenje Treće meditacije otkriva nam prisustvo te nestvorene vječne istine u Descartesovu najvažnijem djelu.

\section{Zaključak}

Iako se danas utjecaj kasne skolastike, posebice Suáreza na oblikovanje Descartesove metafizike i njegove metafizičke teorije ideja prihvaća kao već ustanovljena povijesno-filozofska činjenica, ne možemo ne biti iznenađeni kada usred Treće meditacije, upravo zahvaljujući isusovačkomu misliocu, prepoznamo Cartesiusovu nestvorenu vječnu istinu o postojanju Boga.

U 16. odlomku Treće meditacije vidi se koliko je za Descartesa temeljan kontinuitet s kasnom skolastikom, ali se vide i njegove granice. Tumačenje hipotetičkih tvrdnji iz 16. odlomka kao suarezijanskih vječnih istina razotkrilo je da se Descartesovo razumijevanje tih istina o stvorenjima nalazi na putu mišljenja koji je otvorio Suárez. Bitne razlike između njih ni ne može biti, jer Descartes

22 Tomu mjestu odgovara 15. odlomak Treće meditacije (AT VII 41-42).

23 Ako jedna jest, onda druga mora biti vječna istina o nečemu što se protivi realnoj egzistenciji, dakle o biću razuma.

24 U 16. odlomku ona je formulirana kao posljedica puta meditativnog subjekta, kao dvije hipotetičke tvrdnje, ali relevantno je to da obje tvrde da Bog postoji. 
od Suáreza baštini vezivanje vječnih istina za božansku svemoć, a u kontekstu razumijevanja razlike između essentia i existentia kao razumske. No, Descartes pravi iskorak, vječne istine o stvorenjima čini potpuno zavisnima od Božje volje, istine matematike također, pa čak i načelo neproturječnosti. Zašto on ide dalje od Suáreza, utemeljujući time novovjekovnu metafiziku subjekta, zašto uvodi stvorene, ali i nestvorene vječne istine? ${ }^{25}$ Zašto Suárezovo/skolastičko razumijevanje nije bilo zadovoljavajuće?

Odgovor, jednim dijelom, treba tražiti izvan filozofije: dopuštanje nečega što nije Tvorac, niti je Tvorac njegov uzrok, nekog trećeg „entiteta” — od Boga nezavisnih vječnih istina ili nestvorenog načela neproturječnosti — za Descartesa je čista blasfemija (AT I 145). Za takvo nešto nema mjesta u kršćanstvu: nešto je ili Tvorac ili njegovo stvorenje. Utoliko, slobodno govoreći, Descartes je po tom svojem razumijevanju Boga istinski konsekventni sveopći (catholikos) kršćanski mislilac.

Drugim, povijesno-filozofskim dijelom odgovor se nalazi u Suárezovoj ambivalenciji oko mjesta uzročnosti u odnosu na najtemeljniju razinu biti i vječnih istina, razinu possibile logicum: u čemu se temelji mogućnost realnog egzistiranja biti, na Božjoj svemoći ili na logičnoj neproturječnosti? S obzirom na vječne istine problem glasi: ako počivaju na potentia objectiva, vječne istine podrazumijevaju prisustvo djelotvorne uzročnosti (zavise od Boga), a ako počivaju na possibile logicum nezavisne su od uzročnosti jer possibile logicum nema uzrok. ${ }^{26}$

Upravo je Suárezova ambivalencija na negativan način pripremila Descartesovo učenje o dvije vrste vječnih istina, smanjivši „otpornost“ biti stvorenja na djelotvorno uzrokovanje i stvorivši time potrebu da se vječne istine o Bogu osnaže i odvoje od stvorenog svijeta.

Suárezovu afirmaciju obje mogućnosti možemo promatrati kao „nedostatak“ ili „nedosljednost“, ali to ne pomaže razumijevanju tog mislioca. Promatrajmo je, umjesto toga, kao mjesto otvaranja drugačijih puteva mišljenja jer, baš kao i svi veliki muževi filozofije, i Suárez je mislilac puteva. Descartes je, vidjeli smo, krenuo jednim Suárezovim putem, drugim je krenuo Leibniz: nezavisno od logičke neproturječnosti, bit može imati ili ne imati predikat "moguća realna egzistencija“, a hoće li ga imati ovisi od uklopljenosti njezine realne egzistencije u najbolji od svih mogućih svjetova.

\section{Literatura:}

AT I-XII $=$ René Descartes, Oeuvres de Descartes. Priredili Charles Adam i Paul Tannery. Paris: Vrin, 1897-1913. [Unutartekstna uputnica sadržava kraticu AT, broj knjige i broj stranice, npr.: AT VII 166.]

Cantens, Bernardo (2000). The Relationship between God and Essences and the Notion of Eternal Truths According to Francisco Suárez. The Modern Schoolman, 72(2), $127-143$.

25 O njima i razlici u odnosu na vječne istine o stvorenim stvarima usp.: Wells, 1982; Milidrag, 2006, 224-254.

$26 \mathrm{~S}$ obzirom na temu u ovom radu to nije analizirano. Za rečenu ambivalenciju s odgovarajućim mjestima kod Suáreza usp.: Wells, 1983, 21-27. 
Clemenson, David (2007). Descartes' Theory of Ideas. London: Continuum.

Coombs, Jeffrey (2003). The Ontological Source of Logical Possibility in Catholic Second Scholasticism. U: Russell L. Friedman i Lauge O. Nielsen (ur.), The Medieval Heritage in Early Modern Metaphysics and Modal Theory, 1400-1700 (str. 191-229). Dordrecht: Springer.

Costa, Michael J. (1983). What Cartesian Ideas are Not. The Journal of the History of Philosophy, 21(4), 537-549.

Cronin, Timothy J. (1966). Objective Being in Descartes and in Suárez. Rim: Gregorian University Press.

Descartes, René (1951). Rasprava o metodi. Zagreb: Matica hrvatska.

Descartes, René (1975). Meditacije o prvoj filozofiji. U: Edmund Husserl, Kartezijanske meditacije, I (str. 185-241). Preveo Tomislav Ladan. Zagreb: Izvori i tokovi.

$\mathrm{DM}=$ Francisco Suárez, Disputationes Metaphysicae universam doctrinam duodecim librorum Aristotelis comprehendentes. U: Carolo Berton (prir.), R. P. Francisci Suarez e Societate Jesu Opera Omnia. Vol. 25 i 26. Pariz: Vivès, 1861. [Unutartekstna uputnica sadržava kraticu DM, broj disputacije, broj poglavlja i broj odlomka te broj knjige i stranicu, npr.: DM 8.3.18; vol. 25, 288.]

Doyle, John P. (1967). Suárez on the Reality of the Possibles. The Modern Schoolman, 45(1), 29-48.

Doyle, John P. (1969). Suárez on the Analogy of Being. The Modern Schoolman, 46(3), 219-249; 46(4), 323-341.

Doyle, John P. (1982). The Suarezian Proof of God's Existence. U: Linus Thro J. (ur.), History of Philosophy In the Making: Symposium of Essays to Honour Professor James D. Collins on His 65th Birthday by His Colleagues and Friends (str. 104-117). Washington: University Press of America.

Doyle, John P. (1984). Prolegomena to a Study of Extrinsic Denomination in the Work of Francis Suárez, S.J. Vivarium, 22(2), 121-160.

Doyle, John P. (1987). Suárez on Beings of Reason and Truth. Vivarium, 25(1), 47-75.

Doyle, John P. (1988). Suárez on Beings of Reason and Truth (2). Vivarium, 26(1), 51-72.

Heider, Daniel (2007). Is Suárez's Concept of Being Analogical or Univocal? The American Catholic Philosophical Quarterly, 81(1), 21-41.

Hoeres, Walter (1965). Francis Suárez and the Teaching of John Duns Scotus on „univocatio entis“. U: John Ryan i Bernardine Bonansea (ur.), John Duns Scotus 1265-1965 (str. 263-290). Washington D. C.: The Catholic University of America Press.

Karofsky, Amy (2001a). Suárez' Doctrine of Eternal Truths. The Journal of the History of Philosophy, 39(1), 23-47.

Karofsky, Amy (2001b). Suárez's Influence on Descartes's Theory of Eternal Truths. Medieval Philosophy and Theology, 10(2), 241-262.

Maurer, Armand A. (1990). Being and Knowing: Studies in Thomas Aquinas and Later Medieval Philosophers. Toronto: Pontifical Institute of Mediaeval Studies.

Milidrag, Predrag (2006). Samosvest i moć: Dekartov Bog kao causa sui. Beograd: Okean - Institut za filozofiju i društvenu teoriju.

Milidrag, Predrag (2010a). Dekart, kasna sholastika i istorija filozofije: Slučaj teorije ideja. Filozofija i društvo, 21(1), 187-208.

Milidrag, Predrag (2010b). „Poput slika stvari“: Temelji Dekatove metafizičke teorije ideja. Beograd: Institut za filozofiju i društvenu teoriju.

Milidrag, Predrag (2010c). Princip neprotivrečnosti i Dekartov Bog. Theoria, 53(4), 15-33. 
Milidrag, Predrag (2012a). Katerus i Dekart o idejama, uzrokovanju i večnim istinama. Theoria, 55(1), 45-69.

Milidrag, Predrag (2012b). Objektivna stvarnost, njeni stupnjevi i formalno bivstvovanje (esse) kod Dekarta. Filozofski godišnjak, 25, 113-132.

Milidrag, Predrag (2013). Francisko Suarez o predmetu metafizike. Theoria, 56(2), 61-86.

Miner, Robert C. (2001). Suarez as Founder of Modernity: Reflections on a Topos in Recent Historiography. History of Philosophy Quarterly, 18(1), 17-36.

Mora, Ferrater José (1953). Suárez and Modern Philosophy. The Journal of the History of Ideas, 14(4), 528-543.

Nadler, Steven M. (1989). Arnauld and the Cartesian Philosophy of Ideas. Manchester: Manchester University Press.

Noreña, Carlos G. (1984). Suárez on Metaphysics. Revista de estudios hispánicos, 18(1), 19-32.

Owens, Joseph (1963). An Elementary Christian Metaphysics. Torronto: Bruce Publishing.

Pereira, José (2007). Suárez: Between Scholasticism and Modernity. Milwaukee: Marquette University Press.

Schmitter, Amy M. (1996). Formal Causation and the Explanation of Intentionality in Descartes. The Monist, 79(3), 368-387.

Secada, Jorge (2000). Cartesian Metaphysics: The Late Scholastics Origins of Modern Philosophy. Cambridge: Cambridge University Press.

Toma Akvinski (1996). Opuscula Philosophica: Svezak drugi. Priredio i preveo Augustin Pavlović. Zagreb: Demetra.

Wells, Norman J. (1982). Descartes' Uncreated Eternal Truths. The New Scholasticism, 56(2), 185-199.

Wells, Norman J. (1983). Introduction (3-43). U: Francisco Suárez, On the Essence of Finite Being As Such, on the Existence of That Essence And Their Distinction. Metaphysical Disputation XXXI. Milwaukee: Marquette University Press.

Wells, Norman J. (1984) Material Falsity in Descartes, Arnauld, and Suárez. The Journal of the History of Philosophy, 22(1), 25-50.

Wells, Norman J. (1990). Objective Reality of Ideas in Descartes, Caterus, and Suárez. The Journal of the History of Philosophy, 28(1), 33-61.

Wells, Norman J. (1993). Descartes' Idea and Its Sources. The American Catholic Philosophical Quarterly, 67(4), 513-35. 


\section{Suarez's Eternal Truths and Descartes' Third Meditation}

\section{Predrag Milidrag*}

\section{Summary}

The article analyzes Suárez's understanding of the eternal truths in his 31st Disputation, in regard to the status of creatures in the divine mind and the role of efficient causality. Three points are relevant for an interpretation of Descartes: for Suárez, the eternal truths regarding the essences of creatures express a hypothetical necessity concerning real existence; it is impossible to adequately understand these essences apart from their actual or possible efficient cause; there are eternal truths about entia rationis that express nothing concerning real existence. Part two of the article defends the thesis that Paragraph 16 of the Third Meditation (AT VII 42) contains two Suarezian eternal truths and that from both of these it follows that God exists: from "it could be demonstrated that there exists in the world something apart from myself," it follows that God exists, and from "it cannot be demonstrated that there exists in the world something apart from myself" it also follows that God exists, i.e. myself. Hence, paragraphs 17-22 of the Meditation do not contribute to the proof of God's existence, but they do prove that the subject itself of the Meditations is not God. All of the above leads to the conclusion that paragraph 16 of the Third Meditation in fact contains Descartes' uncreated eternal truth about the existence of God (AT I 150).

Key words: eternal truths, uncreated eternal truths, Meditations, Suárez, Descartes, potentia objectiva, existence of God

* Predrag Milidrag, Ph.D., Senior Research Associate, Institute for Philosophy and Social Theory, University of Belgrade. Address: Kraljice Natalije 45, 11000 Belgrade, Serbia. E-mail: predrag. milidrag@gmail.com 